\title{
Stripping foreign fighters of their citizenship: International human rights and humanitarian law considerations
}

\section{Christophe Paulussen}

Dr Christophe Paulussen LL.M. M.Phil. is a senior researcher at the T.M.C. Asser Instituut and coordinator of its research strand "Human Dignity and Human Security in International and European Law", coordinator of the inter-faculty research platform "International Humanitarian and Criminal Law Platform" and research fellow at the International Centre for Counter-Terrorism - The Hague. Christophe is also editor-inchief of the journal Security and Human Rights, member of the Executive Board of the Royal Netherlands Society of International Law, member of the Editorial Board of the Journal of Human Trafficking, Enslavement and Conflict-Related Sexual Violence and member of the Board of Advisors to the Editorial Board of the Yearbook of International Humanitarian Law. Email: C.Paulussen@asser.nl.

\section{Abstract}

This article will briefly present a number of international human rights law considerations related to the topic of citizenship stripping of foreign fighters, that is: "individuals, driven mainly by ideology, religion and/or kinship, who leave their

(c) The Author(s), 2021. Published by Cambridge University Press on behalf of the ICRC. This is an Open Access article, distributed under the terms of the Creative Commons Attribution licence (http:// creativecommons.org/licenses/by/4.0/), which permits unrestricted re-use, distribution, and reproduction in any medium, provided the original work is properly cited. 
country of origin or their country of habitual residence to join a party engaged in an armed conflict", most notably the conflict in Syria and Iraq. After that, the article will focus on considerations in the context of international humanitarian law, which have been less frequently the subject of academic debate. This contribution concludes that citizenship stripping is not only highly problematic under international human rights law, but also from the perspective of international humanitarian law. The measurewhich is likely to constitute cruel, inhuman or degrading treatment or punishmentviolates Article 3 Common to the four Geneva Conventions, but it also undermines accountability for international humanitarian law violations already committed and can engender new violations through the non-removal of the suspect from the conflict zone. One of the few positive sides of the connection between the measure and international humanitarian law is that even if nationality is deprived, this will not have an effect on the international humanitarian law obligation to treat that deprived person humanely. In that sense, international humanitarian law provides a welcome-albeit temporary-safety net of decent treatment for people who have become victims of countries' refusal to take responsibility for their own citizens.

Keywords: citizenship stripping, deprivation of nationality, foreign fighters, international humanitarian law, international human rights law.

\section{Introduction}

Various armed conflicts around the world have attracted foreign fighters, who have been defined as "individuals, driven mainly by ideology, religion and/or kinship, who leave their country of origin or their country of habitual residence to join a party engaged in an armed conflict". ${ }^{1}$ Examples are the British national George Orwell, who participated in the Spanish civil war in the 1930s on the side of the republicans, the Saudi national Osama bin Laden, who arrived in Afghanistan in

1 A. de Guttry, F. Capone and C. Paulussen, "Introduction", in A. de Guttry, F. Capone and C. Paulussen (eds), Foreign Fighters under International Law and Beyond, Asser Press/Springer: The Hague 2016, p. 2. This definition (and hence also this article) excludes mercenaries, as the latter are motivated to take part in the hostilities essentially by the desire for private gain. See also S. Krähenmann, Foreign Fighters under International Law, Academy Briefing No. 7, Geneva Academy of International Humanitarian Law and Human Rights, Geneva, October 2014, p. 16. However, for a different opinion, see UN General Assembly, Use of Mercenaries as a Means of Violating Human Rights and Impeding the Exercise of the Right of Peoples to Self-determination: Note by the Secretariat, A/73/303, United Nations, New York, 6 August 2018, para. 9: "In the absence of either an internationally agreed legal definition of foreign fighters or a specific regime governing them, the Working Group has defined foreign fighters as individuals who leave their country of origin or habitual residence and become involved in violence as part of an insurgency or non-State armed group in an armed conflict. They are motivated by a range of factors, notably ideology, although the Working Group has found financial motivations to be a key factor as well. In this regard, the Working Group deems foreign fighters as a mercenary-related activity [original footnote omitted]." For more information on the status of foreign fighters under international humanitarian law more generally, see E. Sommario, "The Status of Foreign Fighters under International Humanitarian Law”, in A. de Guttry, F. Capone and C. Paulussen (eds), above, pp. 141-160. 
1980 to challenge the Soviet occupation of that country, and, more recently, the British national Mohammed Emwazi, better known as "Jihadi John", who in 2012 travelled to Syria to join the Islamic State of Iraq and Syria (ISIS) and who would become one of the terrorist organization's most infamous executioners. ${ }^{2}$ Notably the conflict in Syria and Iraq has attracted an unprecedented number of foreign fighters: on 28 November 2017, Vladimir Voronkov, Under-Secretary-General of the United Nations (UN) and Head of its Office of Counter-Terrorism, briefed the UN Security Council and "said that, at one stage more than 40,000 foreign terrorist fighters from 110 countries might have travelled to join the conflict in Syria and Iraq". ${ }^{3}$ Indeed, many of these foreign fighters joined terrorist groups, such as al-Nusra or ISIS, which is why the attention quickly moved from foreign fighters as such to foreign terrorist fighters (FTFs), defined by the UN Security Council as "individuals who travel to a State other than their States of residence or nationality for the purpose of the perpetration, planning, or preparation of, or participation in, terrorist acts or the providing or receiving of terrorist training, including in connection with armed conflict". ${ }^{4}$

In responding to the foreign fighter and especially the FTF phenomenon and the groups that they have joined, states, and international and regional organizations have implemented a broad set of measures, from a full-out military campaign, ${ }^{5}$ to criminal $^{6}$ and administrative measures. ${ }^{7}$ It is interesting to note that in the context of criminal law, the focus has recently shifted from the initial limited counterterrorism perspective-with foreign fighters being mainly prosecuted for membership of a terrorist organization-to broader charges, showing the realization that foreign fighters can also commit crimes as individuals participating in hostilities, such as war crimes. ${ }^{8}$ But as the standards of criminal law may be difficult to meet, especially in view of the difficulty of securing evidence in (post-) conflict situations, states have increasingly resorted to administrative measures. One of these is citizenship stripping or deprivation of

2 See more generally N. Arielli, From Byron to bin Laden: A History of Foreign War Volunteers, Harvard University Press, Cambridge, MA, 2018.

3 UN Security Council, 8116th Meeting (PM), Greater Cooperation Needed to Tackle Danger Posed by Returning Foreign Fighters, Head of Counter-Terrorism Office Tells Security Council, SC/13097, 28 November 2017, available at: https://www.un.org/press/en/2017/sc13097.doc.htm (all internet references were accessed in July 2021).

4 UN Security Council, "Preambular", in Resolution 2178 (2014), S/RES/2178 (2014), 24 September 2014, available at: http://www.securitycouncilreport.org/atf/cf/\%7B65BFCF9B-6D27-4E9C-8CD3-CF6E4FF96FF9\% 7D/s_res_2178.pdf, p. 2.

5 See Operation Inherent Resolve, available at: https://www.inherentresolve.mil/About-CJTF-OIR/.

6 See C. Paulussen and K. Pitcher, "Prosecuting (Potential) Foreign Fighters: Legislative and Practical Challenges", ICCT Research Paper, January 2018, available at: https://icct.nl/app/uploads/2018/01/ICCTPaulussen-Pitcher-Prosecuting-Potential-Foreign-Fighters-Legislative-Practical-Challenges-Jan2018.pdf.

7 See B. Boutin, "Administrative Measures against Foreign Fighters: In Search of Limits and Safeguards", ICCT Research Paper, December 2016, available at: https://icct.nl/app/uploads/2016/12/ICCT-BoutinAdministrative-Measures-December2016-1.pdf.

8 For further information on cumulative prosecution of foreign fighters, see the article by Hanne Cuyckens, "Foreign Fighters and the Tension Between Counterterrorism and International Humanitarian Law: A Case for Cumulative Prosecution Where Possible", in this issue of the International Review of the Red Cross. 
nationality, a measure more and more used by states in the counterterrorism and national security context, including against alleged foreign (terrorist) fighters.

This article will briefly present a number of international human rights law considerations related to the topic of citizenship stripping of foreign fighters before focusing on considerations in the context of international humanitarian law. These are obviously the most interesting for the readers of the International Review of the Red Cross and, moreover, they have been less frequently the subject of academic debate. In the final part of this article, a number of conclusions will be offered.

Before starting though, the relevance of this contribution in this special issue on "Counterterrorism and sanctions" must first be clarified. Indeed, should citizenship stripping or deprivation of nationality (the two terms will be used interchangeably here) be seen as a sanction in the first place? This contribution argues that it should. Although the word "sanction" is often linked to punishment, an objective sometimes lacking in the context of citizenship stripping, ${ }^{9}$ its scope is in fact broader. According to Black's Law Dictionary, a sanction is defined as, among other things, "[a] penalty or coercive measure that results from failure to comply with a law, rule, or order". ${ }^{10}$ Deprivation of nationality in any case fits the second part of this definition. But even if we were to view a sanction to be limited to a penalty, and even if some governments present citizenship stripping as a non-punitive measure meant to protect national security, the connection to crime and punishment is in fact made at other times. Sandra Mantu has, for example, noted that "we are actually witnessing a new way of conceptualising state power whereby depriving individuals of their citizenship status is a form of penal sanction to be applied to citizens in response to perceived crimes against public security by act or by association [original footnote omitted]". ${ }^{11}$ Hence, in all cases, it can be argued that citizenship stripping constitutes a (de facto) sanction, even if we were to follow a definition limited to measures of a punitive nature, and thus fits this special issue.

9 For example, when the Dutch Government, in December 2014, proposed a new bill on the amendment of the Netherlands Nationality Act, to allow the Government to withdraw Dutch citizenship, without a criminal conviction, when the person in question had joined an organization which is taking part in a national or international armed conflict and which has been placed by the Minister of Security and Justice on a list of organizations that constitute a threat to national security, the Minister clarified that the objective of this measure is the protection of national security, which should be distinguished from the objective of using criminal law. See C. Paulussen, "Repressing the Foreign Fighters Phenomenon and Terrorism in Western Europe: Towards an Effective Response Based on Human Rights", ICCT Research Paper, November 2016, available at: https:/icct.nl/app/uploads/2016/11/ICCT-PaulussenRule-of-Law-Nov2016-1.pdf, p. 16. See also, more generally, M. Tripkovic, "Transcending the Boundaries of Punishment: On the Nature of Citizenship Deprivation", British Journal of Criminology, 23 February 2021, available at: https://academic.oup.com/bjc/advance-article-abstract/doi/10.1093/bjc/ azaa085/6146956, abstract: "Departing from a dominant perspective that considers denationalization as punishment, this article conducts an original study of citizenship policies in 37 European democracies and contrasts them with key principles of punishment. The findings raise serious doubts regarding the penal nature of denationalization: I propose instead that denationalization is better understood as a sui generis sanction, which seeks to relieve the polity of those members who fail to satisfy fundamental citizenship requirements."

10 B. A. Garner, Black's Law Dictionary, 8th ed., Thomson West, St. Paul, MN, 2004, p. 1368.

11 S. Mantu, "Citizenship in Times of Terror: Citizenship Deprivation in the UK", Nijmegen Migration Law Working Papers Series, 2015/02, available at: https://repository.ubn.ru.nl/handle/2066/143370, p. 5. 


\section{International human rights law ${ }^{12}$}

This brief part will look at the legality of deprivation of nationality under international human rights law. The measure has an impact on a crucial right, namely the right to nationality, as can be found in various international and regional human rights treaties. ${ }^{13}$ The famous philosopher Hannah Arendt referred in her The Origins of Totalitarianism to "the right to have rights", 14 which clarifies immediately how serious the impact of deprivation of nationality can be. For this reason alone, it has been argued that the measure can never be in compliance with modern international human rights law. ${ }^{15}$ It is submitted that this is indeed correct. According to Article 8, paragraph 1 of the 1961 Convention on the Reduction of Statelessness, "[a] Contracting State shall not deprive a person of its nationality if such deprivation would render him stateless." However, this rule is not the only element to consider. The basic rule of the recent publication Principles on Deprivation of Nationality as a National Security Measure, which was developed after two and half years of research, involving more than 60 international experts and synthesizing all relevant international standards, reads that "States shall not deprive persons of nationality for the purpose of safeguarding national security." 16 The Principles then explain that if this happens nonetheless, "the exercise of this exception should be interpreted and applied narrowly, only in situations in which it has been determined by a lawful conviction that meets international fair trial standards, that the person has conducted themselves in a manner seriously prejudicial to the vital interests of the state". ${ }^{17}$ Moreover, this exception is further limited by other international law standards, including not only the just-mentioned avoidance of

12 This part is based on C. Paulussen, "Towards a Right to Sustainable Security of Person in Times of Terrorism? Assessing Possibilities and Limitations Through a Critical Evaluation of Citizenship Stripping and Non-Repatriation Policies", Journal of Conflict and Security Law, Vol. 26, Issue 1 (Spring 2021), available at: https://doi.org/10.1093/jcsl/kraa022, Section 2.B.

13 See Universal Declaration of Human Rights, Art. 15, para. 1; International Convention on the Elimination of All Forms of Racial Discrimination, Art. 5, para. d(iii); Convention on the Elimination of All Forms of Discrimination against Women, Art. 9; Convention on the Rights of the Child, Arts 7 and 8; American Convention on Human Rights, Art. 20; European Convention on Nationality, Art. 4 (a); Arab Charter on Human Rights, Art. 24; Covenant on the Rights of the Child in Islam, Art. 7; ASEAN Human Rights Declaration, Art. 18; CIS Convention on Human Rights and Fundamental Freedoms, Art. 24. See Institute on Statelessness and Inclusion, Draft Commentary to the Principles on Deprivation of Nationality as a National Security Measure, 2020, available at: https://files.institutesi.org/PRINCIPLES Draft_Commentary.pdf, pp. 27-28.

14 See H. Arendt, The Origins of Totalitarianism, Penguin Classics, Random House UK, London, 2017, pp. 388 and 390. See also L. Faghfouri Azar, "Hannah Arendt: The Right to Have Rights", Critical Legal Thinking, 12 July 2019, available at: https://criticallegalthinking.com/2019/07/12/hannah-arendtright-to-have-rights/.

15 See Office of the United Nations High Commissioner for Human Rights, Amicus Brief, Presented by the UN Special Rapporteur on Contemporary Forms of Racism, Racial Discrimination, Xenophobia and Related Intolerance. Before: The Dutch Immigration and Naturalisation Service, 23 October 2018, available at: https://www.ohchr.org/Documents/Issues/Racism/SR/Amicus/DutchImmigration_Amicus.pdf, para. 25.

16 Institute on Statelessness and Inclusion, Principles on Deprivation of Nationality as a National Security Measure, February 2020, available at: https://www.institutesi.org/year-of-action-resources/principles-ondeprivation-of-nationality, p. 9.

17 Ibid. 
statelessness, but also the prohibition of discrimination, the prohibition of arbitrary deprivation of nationality, the right to a fair trial, remedy and reparation, and other obligations and standards set forth in international human rights law, international humanitarian law and international refugee law. ${ }^{18}$ Zooming in on the prohibition of arbitrary deprivation of nationality, ${ }^{19}$ the Principles clarify that

[t] he deprivation of nationality of citizens on national security grounds is presumptively arbitrary. This presumption may only be overridden in circumstances where such deprivation is, at a minimum: [...] Carried out in pursuance of a legitimate purpose; [...] Provided for by law; [...] Necessary; [...] Proportionate; and [...] In accordance with procedural safeguards. ${ }^{20}$

Zooming in even further on the element of proportionality, the Principles subsequently stipulate that this requires that

[t]he immediate and long-term impact of deprivation of nationality on the rights of the individual, their family, and on society is proportionate to the legitimate purpose being pursued; [...] The deprivation of nationality is the least intrusive means of achieving the stated legitimate purpose; and [...] The deprivation of nationality is an effective means of achieving the stated legitimate purpose. $^{21}$

Similar requirements have been brought forward in a more general way (in his model provision on consistency of counterterrorism practices with human rights and refugee law, and humanitarian law) by the first UN Special Rapporteur on the promotion and protection of human rights and fundamental freedoms while countering terrorism, Martin Scheinin. In his report Ten Areas of Best Practices in Countering Terrorism, Scheinin writes that even if permissible under national law, the exercise of certain functions and powers "may never violate peremptory or non-derogable norms of international law, nor impair the essence of any human right" 22 - such as the principles of non-discrimination and equality- ${ }^{23}$ and

$[w]$ here the exercise of functions and powers involves a restriction upon a human right that is capable of limitation, any such restriction should be to

18 Ibid.

19 See also Institute on Statelessness and Inclusion, above note 13, pp. 43-65; and OSCE Office for Democratic Institutions and Human Rights (ODIHR), Guidelines for Addressing the Threats and Challenges of "Foreign Terrorist Fighters" within a Human Rights Framework, 2018, available at: https://www.osce.org/files/f/documents/4/7/393503_2.pdf, pp. 49-51.

20 Institute on Statelessness and Inclusion, above note 16, p. 10.

21 Ibid., pp. 11-12.

22 Human Rights Council, Report of the Special Rapporteur on the Promotion and Protection of Human Rights and Fundamental Freedoms While Countering Terrorism, Martin Scheinin: Ten Areas of Best Practices in Countering Terrorism, A/HRC/16/51, para. 16.

23 See OSCE Office for Democratic Institutions and Human Rights (ODIHR), above note 19, p. 32; UN Counter-Terrorism Implementation Task Force (CTITF), Working Group on Protecting Human Rights while Countering Terrorism, Basic Human Rights Reference Guide: Security Infrastructure, Updated 2nd ed., March 2014, para. 5; and UN General Assembly, Report of the Special Rapporteur on Contemporary Forms of Racism, Racial Discrimination, Xenophobia and Related Intolerance, A/72/287, 4 August 2017, para. 47. 
the least intrusive means possible and shall: (a) Be necessary in a democratic society to pursue a defined legitimate aim, as permitted by international law; and (b) Be proportionate to the benefit obtained in achieving the legitimate aim in question. ${ }^{24}$

As argued before, ${ }^{25}$ deprivation of nationality can never be seen as the least intrusive means available and be necessary and proportionate. After all, mono-citizens who may have been in the same situation, who may have committed similar crimes and who may pose a similar security risk will not be deprived of their nationality (to avoid statelessness) but will face other, less far-going measures, such as a temporary area ban. If mono-citizens can be responded to in a less intrusive way, then why can these responses not also be applied to dual citizens? This entails that it is extremely difficult to justify deprivation of nationality as the least intrusive and thus necessary and proportionate means towards a certain aim, hence making the measure arbitrary, and thus prohibited under international law. Moreover, as explained above, the measure may never violate peremptory or nonderogable norms of international law, nor impair the essence of any human right, such as the principles of non-discrimination and equality. ${ }^{26}$ In this respect, serious problems under international law arise as well, for the measure can and will only be applied to dual citizens. This clearly creates two different classes of citizens. Indeed, in an amicus curiae brief submitted to the Dutch Immigration and Naturalisation Service, the UN Special Rapporteur on contemporary forms of racism, racial discrimination, xenophobia and related intolerance E. Tendayi Achiume likewise concluded:

The Netherlands' policy to subject Dutch citizens to differential treatment on the basis of their mono or dual citizenship is inconsistent with its international human rights law [obligations]. The Netherlands' policy to use individuals' status as Dutch mono or dual nationals to determine eligibility for citizenship revocation results in discriminatory tiers of citizenship: full citizenship for Dutch mono nationals and less-secure citizenship for Dutch dual nationals. Because this result contradicts its international human rights law obligations to guarantee equality before the law and equal protection of the law to all of its citizens, the Netherlands must not rely on any mono-/dual-nationality distinction in determining permissibility of citizenship revocation. ${ }^{27}$

This brief part has demonstrated that deprivation of nationality is highly problematic under international human rights law. But the measure is also

24 Human Rights Council, above note 22, para. 16.

25 C. Paulussen, above note 12, p. 226.

26 See also Institute on Statelessness and Inclusion, above note 16, p. 10: “[a] State must not deprive any person or group of persons of their nationality as a result of direct or indirect discrimination in law or practice, on any ground prohibited under international law, including race, colour, sex, language, religion, political or other opinion, national or social origin, ethnicity, property, birth or inheritance, disability, sexual orientation or gender identity, or other real or perceived status, characteristic or affiliation."

27 Office of the United Nations High Commissioner for Human Rights, above note 15, para. 36. 
problematic for other reasons. For example, it removes important jurisdictional links to try possible offenders, it undermines international cooperation to fight impunity; it can, through its discriminatory character, lead to even more alienation and resentment and thus possible radicalization in minority groups, who are disproportionally targeted by the measure, and finally it can increase long-term security risks. ${ }^{28}$ Nonetheless, "only" the problematic international human rights law dimension should already be enough to conclude that the measure is not to be resorted to.

\section{International humanitarian law}

Although international human rights law is clearly relevant, and has thus also been discussed in the literature when assessing the legality of the measure, ${ }^{29}$ the centre of attention of this article will be on discussing the measure from a quite novel perspective, that is, in the context of the International Review of the Red Cross's main field of focus: international humanitarian law. Indeed, what are the links between deprivation of nationality and international humanitarian law?

To start with, and this will not come as a surprise, the measure of deprivation of nationality or citizenship stripping itself is not to be found in conventional ${ }^{30}$ and customary ${ }^{31}$ international humanitarian law. This is different for the concept of nationality as such, although it is usually seen as an irrelevant criterion to international humanitarian law, ${ }^{32}$ for instance when it comes to providing protection and care. An example can be found in Article 12 of the First and Second Geneva Conventions, which stipulates that the protected persons of these Conventions "shall be treated humanely and cared for by the Party [Geneva Convention I]/Parties [Geneva Convention II] to the conflict in whose power they may be, without any adverse distinction founded on sex, race, nationality, religion, political opinions, or any other similar criteria". ${ }^{33}$ At other times though, nationality is taken into account, for instance in the context of prescriptions

28 For more on this, see again C. Paulussen, above note 12, pp. 219-249.

29 See especially the work of Laura van Waas in this field, including L. van Waas, "Foreign Fighters and the Deprivation of Nationality: National Practices and International Law Implications", in A. de Guttry, F. Capone and C. Paulussen (eds), above note 1, pp. 469-487.

30 For this purpose, the texts of the four Geneva Conventions and the three Additional Protocols were searched.

31 For this purpose, the Customary International Humanitarian Law Study of the ICRC, Vol. 1: Rules was searched.

32 See e.g. Geneva Convention (I) for the Amelioration of the Condition of the Wounded and Sick in Armed Forces in the Field of 12 August 1949, 75 UNTS 31 (entered into force 21 October 1950) (GC I), Arts 18 and 49; Geneva Convention (II) for the Amelioration of the Condition of Wounded, Sick and Shipwrecked Members of Armed Forces at Sea of 12 August 1949 (entered into force 21 October 1950) (GC II), Arts 14, 30 and 50. Nationality is also irrelevant "for determining whether a particular person can be qualified as a combatant and hence is entitled to POW status (with the possible exception of nationals of the detaining power) [original footnotes omitted]". S. Krähenmann, above note 1, pp. 17-18.

33 See also Geneva Convention (III) relative to the Treatment of Prisoners of War of 12 August 1949 (entered into force 21 October 1950) (GC III), Art. 16; and Geneva Convention (IV) relative to the Protection of Civilian Persons in Time of War of 12 August 1949 (entered into force 21 October 1950) (GC IV), Art. 13. 
regarding the dead, ${ }^{34}$ internment ${ }^{35}$ or "in determining whether civilians in the hands of the enemy are protected under Geneva Convention IV". ${ }^{36}$ As regards the last example, Article 4 of Geneva Convention IV stipulates that

[p]ersons protected by the Convention are those who, at a given moment and in any manner whatsoever, find themselves, in case of a conflict or occupation, in the hands of a Party to the conflict or Occupying Power of which they are not nationals. Nationals of a State which is not bound by the Convention are not protected by it. Nationals of a neutral State who find themselves in the territory of a belligerent State, and nationals of a co-belligerent State, shall not be regarded as protected persons while the State of which they are nationals has normal diplomatic representation in the State in whose hands they are.

Although Geneva Convention IV will usually not be relevant to the phenomenon of foreign fighters, as most of them are involved in non-international armed conflicts, ${ }^{37}$ the provision shows that, in theory, deprivation of nationality could have an effect on an individual's protection. Imagine a foreign fighter who has two nationalities, each of a neutral State, and that the country of second nationality, in contrast to the country of first nationality, has no "normal diplomatic representation in the State in whose hand [the foreign fighter is]". It seems that this would mean that if the country of first nationality revokes nationality, the foreign fighter, now only in the possession of the nationality of the second country, would be regarded as a protected person under Geneva Convention IV, whereas if he or she still had ties to the country which has normal diplomatic representation in the State in whose hands he or she is, he or she would not. Sandra Krähenmann has explained that the exclusions of Article 4 of Geneva Convention IV "are based on the premise that nationals of neutral or co-belligerent states will be protected by their state of origin through normal diplomatic channels, including exercise of diplomatic protection [...], and therefore do not need the additional protection provided by Geneva Convention IV." ${ }^{38}$ But in the case of citizenship stripping, this basic premise is undermined, as the country of origin does not protect its own citizen but, to the contrary, passes the buck to other actors. ${ }^{39}$

The above-mentioned consequence would not only follow for those foreign fighters not directly participating in hostilities (the term foreign fighter is a little

34 See GC I, Art. 17.

35 See GC III, Art. 22; and GC IV, Art. 82.

36 S. Krähenmann, above note 1, p. 18.

37 Ibid., p. 15.

38 Ibid., p. 18.

39 Sandra Krähenmann has noted that the Appeals Chamber of the International Criminal Tribunal for the former Yugoslavia in the Tadić case replaced the nationality standard by the concept of allegiance and that "[a]rguably, a similar reasoning could apply to foreign fighters whose allegiance is not defined by nationality, but religion or ideology. Such an approach might be especially relevant when states of origin show reluctance to exercise diplomatic protection on their behalf [original footnotes omitted]". (Ibid., p. 19.) 
misleading but "join[ing] a party engaged in an armed conflict" does not necessarily mean being involved in direct participation in hostilities, which entails carrying out "specific acts $[\ldots]$ as part of the conduct of hostilities between parties to an armed conflict"). ${ }^{40}$ Also "[c]ivilians who directly participate in hostilities [...] remain protected civilians when they fall into the hands of the enemy, provided they fulfil the nationality criteria set out in Article 4". ${ }^{41}$

It is also interesting to see where nationality is not mentioned in the different texts. For instance, in paragraph 1 of Article 3 common to the four Geneva Conventions - and this provision is of course of particular interest to the phenomenon of foreign fighters, as most of these fighters are active in noninternational armed conflicts - nationality is not listed as a prohibited ground for adverse distinction among protected persons:

Persons taking no active part in the hostilities, including members of armed forces who have laid down their arms and those placed hors de combat by sickness, wounds, detention, or any other cause, shall in all circumstances be treated humanely, without any adverse distinction founded on race, colour, religion or faith, sex, birth or wealth, or any other similar criteria.

The question is of course whether nationality would fall under the concept of "other similar criteria"? According to the 2016 Commentary to common Article 3, that is indeed the case. Although

the Working Party preparing the draft of the final text of common Article 3 at the 1949 Diplomatic Conference [...] decided not to include nationality as a criterion, given that it might be perfectly legal for a government to treat insurgents who are its own nationals differently in an adverse sense from foreigners taking part in a civil war [for instance "foreign fighters"], ${ }^{42}$

this different treatment "has no bearing on common Article 3's imperative of humane treatment without any adverse distinction." ${ }^{43}$ Hence, although "[i]n the domestic judicial assessment of a non-international armed conflict, nationality may be regarded as an aggravating or extenuating circumstance, $[\ldots]$ it cannot be regarded as affecting in any way the humanitarian law obligation of humane treatment [emphasis added]". ${ }^{4}$

To conclude this part, the measure of deprivation of nationality or citizenship stripping cannot be found in international humanitarian law and the concept of nationality is irrelevant when it comes to fundamental guarantees of humane treatment under international humanitarian law. Indeed, in theory states

40 "Interpretive Guidance on the Notion of Direct Participation in Hostilities under International Humanitarian Law, Adopted by the Assembly of the International Committee of the Red Cross on 26 February 2009", International Review of the Red Cross, Vol. 90, No. 872 (December 2008), available at: https://www.icrc.org/en/doc/assets/files/other/irrc-872-reports-documents.pdf, p. 995.

41 S. Krähenmann, above note 1, p. 18.

42 ICRC, Commentary of 2016. Article 3: Conflicts not of an International Character, available at: https://ihldatabases.icrc.org/applic/ihl/ihl.nsf/Comment.xsp?action=openDocument\&documentId=59F6CDFA490736 C1C1257F7D004BA0EC, para. 571.

43 Ibid., para 572.

44 Ibid. 
could deprive someone of nationality under domestic law, ${ }^{45}$ but that deprivation cannot affect that person's humane treatment under international humanitarian law.

A clearer link between the measure and international humanitarian law can be identified in the following context: according to Rule 158 of the Customary International Humanitarian Law Study of the ICRC, Vol. 1: Rules, "States must investigate war crimes allegedly committed by their nationals or armed forces, or on their territory, and, if appropriate, prosecute the suspects. They must also investigate other war crimes over which they have jurisdiction and, if appropriate, prosecute the suspects." ${ }^{46}$ It is undisputed that foreign fighters, often as members of groups such as ISIS, have committed the most horrible war crimes. ${ }^{47}$ It can be argued that if states, rather than investigating the war crimes allegedly committed by their nationals, instead rescind responsibility by depriving them of their nationality and make their former nationals the problem of other actors, they violate this customary international humanitarian law obligation. Indeed, as also briefly mentioned at the end of the previous part, deprivation of nationality removes an important jurisdictional link to try possible offenders, the active nationality principle, and thus undermines the fight against impunity. ${ }^{48}$ By violating this customary international humanitarian law obligation, states also violate the more general obligation of UN Security Council Resolution 2178, the most authoritative resolution on the phenomenon of FTFs, that "Member States must ensure that any measures taken to counter terrorism [such as deprivation of nationality] comply with all their obligations under international law, in particular international human rights law, international refugee law, and international humanitarian law". 49

45 Although the conclusion of the previous part should be repeated here again, namely that under international human rights law, the measure is highly problematic.

46 J.-M. Henckaerts and L. Doswald-Beck, Customary International Humanitarian Law, Vol. 1: Rules, Cambridge University Press: Cambridge, 2005 (reprinted with corrections 2009), p. 607.

47 See e.g. Eurojust, Network for Investigation and Prosecution of Genocide, Crimes against Humanity and War Crimes, Cumulative Prosecution of Foreign Terrorist Fighters for Core International Crimes and Terrorism-related Offences, The Hague, May 2020, available at: https://www.eurojust.europa.eu/sites/ default/files/Partners/Genocide/2020-05_Report-on-cumulative-prosecution-of-FTFs_EN.PDF, pp. 12-13: "The Reports of the Independent International Commission of Inquiry on the Syrian Arab Republic (UN CoI Syria) stated that ISIS had endangered and directed acts of violence against the civilian population in areas controlled by them, and persons not taking part in hostilities. Accordingly, they committed the war crimes of murder, execution without due process, mutilation, enforced disappearance, torture, cruel treatment, hostage-taking, rape and sexual violence, forced pregnancy, the use and recruitment of children in hostilities and attacking protected objects, forcibly displacing civilians, outrages upon personal dignity as well as other serious violations of IHL [international humanitarian law]. ISIS violated its obligations towards civilians and persons hors de combat which amounted to war crimes by beheading, shooting and stoning men, women, children and captured soldiers. They mutilated their bodies and carried out amputations and lashings in public spaces. Prisoners of ISIS had to survive beatings, whipping, electrocution, and suspension from walls or ceilings. Moreover, ISIS was engaged in abductions, and women and girls suffered from sexual slavery, gang raping, executions for unapproved contact with the opposite sex and stoning for adultery. According to the UN CoI Syria, the commanders of ISIS had wilfully perpetrated these war crimes with the indisputable intent of attacking persons while they were aware of their status as civilians or persons no longer participating in hostilities. Yazidis were especially targeted by horrific abuse by ISIS due to their community's religious identity [original footnotes omitted]."

48 H. Cuyckens, above note 8, "Domestic prosecution in the country of origin" section.

49 UN Security Council, above note 4, p. 1. 
It is admitted that stripping of citizenship and thus the removal of the active nationality principle does not mean that investigation and prosecution of war crimes committed by one's former nationals will never be possible. After all, Rule 157 of the same Customary International Humanitarian Law Study of the ICRC, Vol. 1: Rules clarifies that "States have the right to vest universal jurisdiction in their national courts over war crimes"..$^{50}$ However, in practice, one can see that investigation and prosecution based on "pure" universal jurisdiction ${ }^{51}$-especially after Belgium experienced the political consequences of such a broad law -52 are scarce, and that the exercise of universal jurisdiction has now often been made dependent on certain conditions. In the Netherlands, for example, the International Crimes Act of 2003 stipulates that universal jurisdiction for international crimes such as war crimes committed abroad is conditional upon the suspect's presence in the Netherlands..$^{53}$ Hence, if a Dutch foreign fighter's citizenship is stripped, prosecution for war crimes may still be possible under universal jurisdiction, but only if that person is present in the Netherlands, which often will not be the case. It has therefore also been argued that the Netherlands should stop applying the measure of deprivation of nationality, for it undermines accountability efforts among other things, not only in the context of terrorist crimes, but also in the context of international crimes such as war crimes. ${ }^{54}$ Going further, the point could be made that if a state does not bring its foreign fighters to justice (either in its own courts or elsewhere), it will not only undermine the fight against impunity for crimes already committed, but also it may lead to a prolongation of the conflict, ${ }^{55}$ which, in turn, will lead to new international humanitarian law violations. ${ }^{56}$

50 J.-M. Henckaerts and L. Doswald-Beck, above note 46, p. 604.

51 "Pure universal jurisdiction takes place when a state asserts jurisdiction (either through an investigation or by seeking extradition) of a suspect who is not present in the state's territory." See International Center for Transitional Justice, Advancing Global Accountability: The Role of Universal Jurisdiction in Prosecuting International Crimes, December 2020, available at: https:/www.ictj.org/sites/default/files/ICTJ_Report_ Universal_Jurisdiction.pdf, p. 13.

52 See e.g. S. R. Ratner, “Belgium's War Crimes Statute: A Postmortem”, American Journal of International Law, Vol. 97, No. 4, 2003, pp. 888-897.

53 Netherlands International Crimes Act, 2003, Section 2, para. 1 (a).

54 See C. Paulussen, Reactie op het wetsvoorstel permanentmaking bevoegdheid tot intrekking Nederlanderschap in het belang van de nationale veiligheid (Keten-ID: 10430), 25 January 2021, available at: https:/www.internetconsultatie.nl/intrekkingnederlanderschap/reactie/152199/bestand, pp. 4-6.

55 See also UN Security Council, "Preambular: 'Concerned that foreign terrorist fighters increase the intensity, duration and intractability of conflicts", in Resolution 2178 (2014), S/RES/2178 (2014), 24 September 2014, available at: http://www.securitycouncilreport.org/atf/cf/\%7B65BFCF9B-6D27-4E9C8CD3-CF6E4FF96FF9\%7D/s_res_2178.pdf, p. 2.

56 See also Council of Europe Parliamentary Assembly, Withdrawing Nationality as a Measure to Combat Terrorism: a Human-rights Compatible Approach?, Resolution 2263 (2019), available at: http://assembly. coe.int/nw/xml/XRef/Xref-XML2HTML-en.asp?fileid=25430\&lang=en, para. 8: "The Assembly also notes that the practice of depriving of their nationality persons involved in terrorist activities (including "foreign fighters") or suspected of such involvement may lead to the "exporting of risks", as those persons may move to or remain in terrorist conflict zones outside Europe. Such a practice goes against the principle of international co-operation in combating terrorism, reaffirmed, inter alia, in UN Security Council Resolution 2178 (2014), which aims at preventing foreign fighters from leaving their State of residence or nationality, and may expose local populations to violations of international human rights and humanitarian law." 
Finally, the already mentioned Principles on Deprivation of Nationality as a National Security Measure clarify in Principle 9.3.2 that "[d] eprivation of nationality is likely to constitute cruel, inhuman or degrading treatment or punishment, particularly where it results in statelessness" ${ }^{57}$ As regards the deprivation itself: the Draft Commentary to the Principles, referring to the cases Maritza Urrutia v. Guatemala (Inter-American Court of Human Rights) ${ }^{58}$ and Trop v. Dulles (United States Supreme Court), ${ }^{59}$ explains that the measure "may cause severe mental suffering, as the identity of the person concerned has been taken away and that person is left in a state of uncertainty." ${ }^{60}$ In addition to the deprivation itself, measures following citizenship stripping, such as statelessness, ${ }^{61}$ could even amount to torture. ${ }^{62}$ As such, citizenship stripping is a violation not only of international human rights law, but also of international humanitarian law, such as common Article 3. This provision was applicable to several Western countries depriving their former citizens of nationality as these countries, such as the Netherlands and the United Kingdom, were "involved in the non-international armed conflicts against the Islamic State group in Iraq and Syria by undertaking airstrikes as part of the international coalition led by the United States." 63

\section{Conclusion}

This brief contribution has demonstrated that depriving foreign fighters of their nationality is problematic from a variety of perspectives, not only from an international human rights law point of view (in which context the measure has already been addressed before), but also from the standpoint of the International Review of the Red Cross's main field of focus: international humanitarian law. As just mentioned, the measure in itself - which is likely to constitute cruel, inhuman or degrading treatment or punishment-violates common Article 3. However, also from a more indirect standpoint the measure should not be resorted to: it clearly undermines accountability for international humanitarian law violations already committed and can engender new violations through the non-removal of the suspect from the conflict zone. One of the few positive sides of the connection between the measure and international humanitarian law is that even

57 Institute on Statelessness and Inclusion, above note 16, p. 14.

58 Institute on Statelessness and Inclusion, above note 13, p. 77: "the elements of the concept of torture [...] include methods to obliterate the personality of the victim in order to attain certain objectives, such as intimidation or punishment."

59 Ibid.: "[T]he punishment [of denaturalization is cruel and unusual as it] strips the citizen of his status in the national and international political community. [...] In short, the expatriate has lost the right to have rights." Here, the Supreme Court is clearly echoing the earlier-mentioned words of Hannah Arendt.

60 Ibid.

61 It is recalled that deprivation of nationality may not lead to statelessness; see the earlier reference to the 1961 Convention on the Reduction of Statelessness. However, in practice, this still happens, either de jure or de facto.

62 Institute on Statelessness and Inclusion, above note 13, p. 77.

63 Geneva Academy, RULAC, Netherlands, available at: https:/www.rulac.org/browse/countries/thenetherlands. 
if nationality is deprived, this will not have an effect on, for example, the international humanitarian law obligation to treat that deprived person humanely. In that sense, international humanitarian law provides a welcomealbeit temporary-safety net of decent treatment for people who have become victims of countries' refusal to take responsibility for their own citizens. 